Seton Hall University

eRepository@Seton Hall

Praxis Publications

Praxis Program of the Advanced Seminar on

Mission

$11-2017$

\title{
Enhancing information literacy using Bernard Lonergan's Generalized Empirical Method: A three-year case study in a first year biology course.
}

Lisa M. Rose-Wiles

Seton Hall University, lisa.rose-wiles@shu.edu

Marian Glenn

Seton Hall University

Doreen Stiskal

Seton Hall University

Follow this and additional works at: https://scholarship.shu.edu/praxis-publications

Part of the Biology Commons, Comparative Methodologies and Theories Commons, and the Information Literacy Commons

\section{Recommended Citation}

Rose-Wiles, Lisa M.; Glenn, Marian; and Stiskal, Doreen, "Enhancing information literacy using Bernard Lonergan's Generalized Empirical Method: A three-year case study in a first year biology course." (2017). Praxis Publications. 2.

https://scholarship.shu.edu/praxis-publications/2 
Enhancing information literacy using Bernard Lonergan's Generalized Empirical Method:

A three-year case study in a first year biology course.

Lisa Rose-Wiles $^{\mathrm{a}}$, Marian Glenn ${ }^{\mathrm{b}}$ and Doreen Stiskal ${ }^{\mathrm{c}}$

\section{PREPRINT}

Accepted by the Journal of Academic Librarianship, August 23, 2017

For final version, see Volume 43, Issue 6, November 2017, Pages 495-508

https://doi.org/10.1016/j.acalib.2017.08.012

a. Corresponding Author. Seton Hall University Libraries. Seton Hall University, 300 South Orange Avenue, South Orange, NJ. 07079.

Email: lisa.rose-wiles@ shu.edu

Telephone: 973-275-2047

Fax: 973-761-9432

b. Seton Hall University Department of Biological Sciences

c. Seton Hall University Department of Physical Therapy 
PREPRINT: Enhancing information literacy using Bernard Lonergan's Generalized Empirical Method 


\section{Introduction}

The purpose is to illustrate how a team of 3 faculty from different disciplines sought to increase select information literacy outcomes of first year biology students using Bernard J. Lonergan's cognitional theory, the Generalized Empirical Method (GEM). The majority of students entering college have little experience in finding, retrieving, understanding, evaluating, incorporating, and citing scholarly sources in their scientific research papers. One factor may be a lack of library instruction and research experience in high school (Head, 2013; Smith et al., 2013; Douglas \& Rabinowitz, 2016). Even for those with prior instruction, transitioning from high school level assignments to college level research can be a formidable challenge (Bent, 2008; Warwick et al., 2009; Varlejs et al., 2014; Loesch, 2017). In addition, few students understand the system of scholarly publishing or the structure of scientific information (Badke, 2012). They do not grasp the relationship between articles, journals, and library databases or the difference between searching a scientific database and using search engines such as Google. In her seminal paper "Desperately Seeking Citations: Uncovering faculty assumptions about the undergraduate research", Leckie (1996) describes how undergraduates have only the vaguest ideas about the research and scholarly publication process; they conceptualize research as "a fuzzy, library-based activity that is required of them to complete their coursework" (p. 202-203). A follow-up report (Rose-Wiles \& Hofmann, 2013) suggests that little has changed in almost three decades, and that dependence on databases and on-line articles, rather than searching in physical journals, makes the library-based research process even more confusing for naïve undergraduate students.

Science is a research-driven discipline, and therefore students should possess the requisite search skills. They have heard of the scientific method, but seem to associate it solely with completing hands-on experiments or Eureka style discovery rather than with background reading, hypothesis formation and testing and finally communication of results. As Cervetti and Pearson (2012) note, students treat science texts as if they contained established truths, without understanding how facts are determined or thinking of science as way of answering questions. Furthermore, most first year science students do not know how 
to generate interesting research questions that would lead to the discovery of new information and contribute to their learning. Even within a science course, the students' laboratory experiences seldom go beyond replicating well-established observations, with minimal dialog when reporting the results.

Students often lack an understanding of how a literature search contributes to an in-depth discussion of their laboratory results. Thus to succeed in college, students must transition from replication of data obtained in a highly structured laboratory experience to one where they are expected to be active participants in facilitating their own learning (Smith et al., 2013). They also need to understand the research process and, as stated in the ACRL Framework for Information Literacy for Higher Education, realize that information creation is a process and that research is an open-ended exploration and engagement with information (ACRL 2016).

Information literacy is particularly important in the sciences, including biology (Brown \& Krumholz, 2002; Freeman and Lynd-Balta, 2010; Ferrer-Vinent et al. 2015; Thompson \& Blankinship, 2015; Jacobs et al. 2016). Robinson and McDonald (2014) relate information literacy to higher level skills, such as critical and creative thinking. Lantz (2016) notes that success in the sciences depends on mastering the scientific literature, including how to find and analyze scientific writing. Thompson \& Blankinship (2015) similarly note that "weak information literacy skills produce weak research, which limits student success” (p. 29). However, as Bandyopadhyay (2013) reports, biology undergraduates often lack a fundamental understanding of the biological literature. This trend also appears in graduate students who typically oversee first year laboratory courses, as they often struggle with information literacy themselves (Lantz, 2016). The addition of a skilled librarian may help address these problems.

Numerous studies acknowledge the value of information literacy instruction and the direct involvement of librarians in biology classes and laboratories (e.g. Bowden \& DiBenedetto, 2001; Firooznia \& Andreadis, 2006; Jacob and Heisel, 2008; Winterman, 2009; Ferrer-Vinent \& Carello, 2011, Fuselier \& Nelson, 2011; Gregory, 2013; Hartman et al., 2014; Kim \& Shumaker, 2015; Brancato et al., 2016). Collaborations between librarians and faculty have a long history (Drewes \& Hoffman, 2010). 
PREPRINT: Enhancing information literacy using Bernard Lonergan's Generalized Empirical Method

Recently these associations have expanded to include instruction and other services focused primarily on students' information literacy and research skills (e.g. Arp et al., 2006; Brasley, 2008; Douglas \& Rabinowitz, 2016). The practice of having an embedded librarian working in partnership with teaching faculty has gained traction with the rapid expansion of digital information resources (Abrizah et al., 2016). Reale (2015) defines an embedded librarian simply as one "situated within and among those whom one is serving" (p. 8). Instead of waiting for requests for research assistance or library instruction sessions, embedded librarians participate in the designing and teaching of information literacy components delivered in online, face-to-face and hybrid courses in their areas of subject expertise. More often, the librarians join in the actual teaching environment (e.g. Kesselman \& Watstein, 2009; FerrerVincent \& Carell, 2011; Leonard \& McCaffrey, 2014; Freiburger et al., 2016; Reed \& Thompson, 2016). Dewey (2004) envisions librarians "embedded" in almost all aspects of campus life (see also Drewes \& Hoffman, 2010). Effective information literacy instruction is particularly important for students in first year general biology courses, which are pivotal for life science majors (Lantz, 2016) and also capture a diverse group of science students (Bowden \& DiBenedetto, 2001). Mobilizing librarians directly to engage with first year students in such courses affords an excellent way to address the behavioral and cognitive deficits noted in the literature and in practice.

\section{Background}

Seton Hall University (SHU) is a Catholic diocesan, doctoral research university with a balance of arts and sciences and professional education, located in South Orange, NJ. As of fall 2015, SHU had an enrollment of 9,104, comprised of 6,090 undergraduates and 3,014 graduate students (SHU Fact Book 2015-16). About $25 \%$ of the University's undergraduates were freshmen. The Department of Biological Sciences has 618 declared undergraduate majors, including 357 students undertaking joint degrees with Physical Therapy, Athletic Training or Physician Assistant programs. The Department also had 63 graduate students, many of whom serve as Teaching Assistants (TA's) and lead the majority of undergraduate laboratory sections. 
Information literacy is among the core proficiencies required of all undergraduates (Bloom, 2007). SHU librarians maintain a vigorous and expanding information literacy program that contributes to student development in this proficiency. First year students have information literacy instruction through a general freshman orientation, followed by an assignment-focused library orientation session in each of two sequential first-year English courses. Many students receive additional subject-specific sessions in other introductory courses as well. However, a combination of time pressure due to heavily content-driven syllabi and a high student to librarian ratio means that these library sessions are generally "one shot" affairs rather than sequential or embedded sessions across or within courses. Probably the greatest challenge to the library instruction program is the lack of follow up sessions, which limits opportunities for a scaffolded approach to learning.

\section{The Praxis Program of the Advanced Seminar on Mission}

As a major Catholic University, SHU is mission-centered and committed to student and faculty development. The Center for Catholic Studies sponsors an annual faculty development seminar on some aspect of the Catholic intellectual tradition, open to all faculty. The Center for Vocation and Servant Leadership (CVSL), founded in 2003 with the support of the Lilly Foundation, developed a sequence of seminars to explore the role of the university in the generation, application, and transmission of knowledge based on the principles of Bernhard J. Lonergan, a Jesuit philosopher and theologian. In spring 2013, the CVSL initiated the Praxis of the Advanced Seminar on Mission ("Praxis") co-sponsored with the Center for Catholic Studies and the Bernard J. Lonergan Institute. The program is designed to “engage faculty and administrators in a process of peer mentoring and curricular/co-curricular support designed to apply the mission of the University to their respective disciplines and departments, through a method which connects the disciplines to each other, to an integrated understanding of knowledge, and to the Catholic Intellectual Tradition.” For further details of the Praxis Program, see Liddy (2014) and the Praxis Program website. The authors of this manuscript are members of the Praxis group and remain actively involved with the program. 
PREPRINT: Enhancing information literacy using Bernard Lonergan's Generalized Empirical Method

Bernhard J. Lonergan sought to reconcile theology and the natural sciences through an analysis of the common method that generates a person's knowledge. His best known works are Insight: A Study of Human Understanding (Lonergan, 1957; 1992) and Method in Theology (Lonergan, 1971; 1990).

Lonergan's cognitive theory, called the Generalized Empirical Method (GEM) brings cohesion to knowledge across disciplines, by asking, "What is knowing?" The GEM introduces a set of precepts to explain the progression of coming to know through a dynamic process involving experience, understanding, judgment, and action (Lonergan 1971; 1990). A person proceeds through these precepts by insight and self-reflection (Cronin 2001). Lonergan also had a strong interest in education (Lonergan, 1993; 2005). His GEM provides a framework that can be applied in any discipline, including the sciences, to "bridge the gap between lecturing and hands-on learning" (Marroum, 2004, p. 521). As Roscoe (2004) suggests, Lonergan offers a way to reconcile constructivist theories of learning, which hold that students form their own knowledge, and traditional 'realism' that emphasizes instruction of the student. For Lonergan, the presentation of content and individual construction of concepts "does not constitute a dichotomy, but simply different parts of the same process of knowing" (Roscoe, 2004, p. 550; see also Kirschner \& van Merriënboer, 2013).

GEM provides a valuable framework for conducting research, including field, laboratory and/or library research. The four elements of GEM - Experience, Understanding, Judging, and Acting - correlate well with basic steps in the research process (Table 1). For example, "experience" links equally well to conducting an experiment or a literature review; "understanding" relates directly to interpreting the results of an experiment, the relevant scientific literature, and the relationship between the two. The authors felt that GEM could usefully be introduced into a first year biology lab to foster students' learning and research abilities. 


\section{Applying Lonergan's Generalized Empirical Method}

The Praxis program sponsored by CVSL requires each faculty participant to prepare, carry out, and evaluate a practical application of Bernard Lonergan's GEM. These practical applications are referred to as "Applying the Method" or ATM. The first two authors, as part of the first group of Praxis

Table 1: Components of Bernard Lonergan's Generalized Empirical Method (GEM) Applied to a First Year Biology Laboratory Course (a) Lab Experiments and (b) Library Research.

\section{EXPERIENCE --- be attentive}

a. Your experiment is the experience, so pay attention to what you are doing and what you are observing. This is your raw data. Record your methods and results carefully for later transcription into your lab report.

b. In your library research, your experience is searching for and finding appropriate sources (articles); be attentive to how you search and what you find.

2. UNDERSTANDING - be intelligent

a. In your experiment, think about (reflect on) what you observe. Why did this happen, what does it mean? Look for meaning or pattem in the data and be open to insights.

b. In your library research, what are the authors of the articles you read saying? Do you understand the articles and how they relate to your experiment?

3. JUDGING - be reasonable

a. In your experiment, did you get the results you expected from your reading of previous work? If not, why not? What other questions might you ask? This will be the basis of the discussion in your lab report.

b. In your library research, which articles are you going to choose to incorporate into your paper? Which articles are relevant to your understanding and why?

4. ACTING - be responsible

a. How do your experiment and your results relate to what others did? What is the significance of this experiment? What predictions might you make to test your theory? This forms the basis of your lab report discussion.

b. In your library research - where and how will you incorporate and cite the sources that you choose? Have you made ethical use of the information you found and cited it correctly?

participants, initially prepared their ATM applications individually: “Applying Generalized Empirical Method to Library Instruction" (Author 1) and "Generalized Empirical Method Applied to the Study of the Natural Sciences" (Author 2). Subsequently, great value could be seen in combining efforts through collaborative teaching. A key component of the newly combined ATM activity was to provide a framework for teaching information literacy and the research process using a simplified rubric of Lonergan's GEM. While GEM can be applied to any discipline, it seemed particularly applicable to the 
empirical sciences. Indeed, Lonergan's “generalized empirical method may be understood as the scientific method expressed in cognitional terms" (Grallo, 2016, p. 56).

The authors had two opportunities to implement their comingled ATM projects within a single semester. While the first was to a cohort of students enrolled in a third year Biology elective, "Engaging the World: Ecology and Stewardship", the application of the ATM within a required first year course: "General Biology: Organisms" best addressed the lack of skill in writing laboratory science reports earlier in college. In both courses, the applied GEM framework allowed an embedded librarian to work with principal biology instructors and TA's to enhance core proficiency in information literacy. In this paper, the evolution of the ATM project as part of the Praxis program is presented as it was implemented in the General Biology course during five sequential semesters, spring 2014 through spring 2016.

\section{Integrating Information Literacy in a First Year Biology Lab}

Starting with the spring 2014 semester, Authors $1 \& 2$ collaborated to introduce an information literacy component into the laboratory sections of General Biology (BIOL 1201), which is the first part of a two-semester course of introductory biology required of biology majors. The course's emphasis is on the organismal level rather than a cellular or molecular level. Content includes a survey of protists, plants, and animals, which is followed by discussions of how all living things fit into the biosphere and the underlying theme of biodiversity. Written assignments assist in the development of reading and writing skills in the biological sciences to improve depth of understanding of the material and to facilitate the interpretation of different biological questions based on interactions in class and/or laboratory. These written tasks include preparing formal laboratory reports based on the conventions of scientific papers. In addition to the typical weekly schedule of three lecture periods, a two-to-three hour laboratory session taught by TA's under the guidance of the biology faculty member was a component of the course. The enrolled students selected a laboratory section that accommodated up to18 students. Given the contentrich lecture component of General Biology, with no time available for information literacy instruction, the embedded librarian focused on the laboratory sessions to interact with students. 
First Iteration: Spring 2014

The spring 2014 course had 52 students enrolled into three lab sections (Table 2). Each student was assigned five formal lab reports describing the experiments that were performed in pairs during the laboratory periods. The lab reports followed the format of a scientific paper (abstract, introduction, methods, results, discussion, conclusion, and references) and each submission required the incorporation of at least three scholarly sources. To grade the latter portion of the reports, i.e. the selection and use of references, the librarian employed a rubric prepared in collaboration with the primary Biology 1201 instructor. Both tested the rubric extensively with the two TA's assigned to the laboratory sections prior to use during the course. The rubric allotted points for scholarly sources drawn from the scientific literature, their relevance to the topic, their incorporation into the lab report and the use of correct citation protocol and style (Figure 1). The librarian emphasized the correspondence between the four elements of the rubric (sources, relevance, integration, and citation) and the four elements of GEM - experience, understanding, judgment, and action (Table 1) since the GEM framework would form an integral aspect of the underlying pedagogy and the librarian's role in the course.

Table 2: Sections of Biology 1201 Labs with embedded librarian

\begin{tabular}{|l|c|c|c|c|c|}
\hline Semester & Sections & Students & Lab Reports & $\begin{array}{c}\text { Average } \\
\text { completed }\end{array}$ & $\begin{array}{c}\text { Graded by } \\
\text { Librarian }\end{array}$ \\
\hline Spring 2014 & 3 & 52 & 5 & $64 \%$ & 167 \\
\hline Fall 2014 & 17 & 287 & 4 & $\mathrm{n} / \mathrm{a}$ & 66 \\
\hline Spring 2015 & 3 & 49 & 3 & $86 \%$ & 126 \\
\hline Fall 2015 & 18 & 309 & 4 & $\mathrm{n} / \mathrm{a}$ & 140 \\
\hline Spring 2016 & 3 & 46 & 4 & $79 \%$ & 145 \\
\hline
\end{tabular}

Fall 2015: Added library skills pre- and post-test, 3 library exercises (graded on Blackboard) Spring 2016: Added 2 annotated bibliography assignments; all grading moved to Blackboard 
PREPRINT: Enhancing information literacy using Bernard Lonergan's Generalized Empirical Method

Figure 1: Initial Reference Grading Rubric for Biology 1201, spring 2014

\begin{tabular}{|c|c|c|c|c|}
\hline Component & Excellent (5) & Good (4) & Satisfactory (3) & $\begin{array}{l}\text { Needs significant } \\
\text { improvement }(0-2)\end{array}$ \\
\hline $\begin{array}{l}\text { Number \& Quality of } \\
\text { sources }{ }^{1} \text { (Experience) }\end{array}$ & $\begin{array}{l}3 \text { or more appropriate } \\
\text { scholarly articles; may } \\
\text { have additional sources }\end{array}$ & $\begin{array}{l}2 \text { appropriate } \\
\text { scholarly articles; may } \\
\text { include additional } \\
\text { sources }\end{array}$ & $\begin{array}{l}1 \text { appropriate } \\
\text { scholarly article, may } \\
\text { include additional } \\
\text { sources }\end{array}$ & $\begin{array}{l}\text { No appropriate } \\
\text { scholarly articles }\end{array}$ \\
\hline $\begin{array}{l}\text { Relevance of articles } \\
\text { (Understanding) }\end{array}$ & $\begin{array}{l}\text { all sources highly } \\
\text { relevant to topic }\end{array}$ & $\begin{array}{l}\text { at least } 2 \text { sources very } \\
\text { relevant }\end{array}$ & $\begin{array}{l}\text { at least } 1 \text { source very } \\
\text { relevant }\end{array}$ & no relevant sources \\
\hline $\begin{array}{l}\text { Integration of sources } \\
\text { (Judgment) }\end{array}$ & $\begin{array}{l}\text { all sources well } \\
\text { integrated, evidence of } \\
\text { good judgment in use } \\
\text { of sources, minimal } \\
\text { direct quotations }\end{array}$ & $\begin{array}{l}\text { at least } 2 \text { scholarly } \\
\text { articles well } \\
\text { integrated }\end{array}$ & $\begin{array}{l}\text { at least } 1 \text { scholarly } \\
\text { article well integrated }\end{array}$ & $\begin{array}{l}\text { scholarly articles not } \\
\text { well integrated }\end{array}$ \\
\hline Citations (Action) & $\begin{array}{l}\text { all citations listed } \\
\text { correctly in reference } \\
\text { list and all references } \\
\text { correctly cited in text, } \\
\text { any quotations } \\
\text { correctly attributed, } \\
\text { proper citation style }\end{array}$ & $\begin{array}{l}\text { only one citation } \\
\text { omitted; may have } \\
\text { minor citation errors } \\
\text { (e.g. missing } 2 \text { nd } \\
\text { author, missing } \\
\text { journal title, volume } \\
\text { or page numbers) }\end{array}$ & $\begin{array}{l}\text { two citations missed } \\
\text { OR significant citation } \\
\text { errors }\end{array}$ & $\begin{array}{l}\text { more than two } \\
\text { omissions and/or } \\
\text { direct quotation with } \\
\text { no attribution; major } \\
\text { citation errors }\end{array}$ \\
\hline
\end{tabular}

${ }^{1}$ Articles or scholarly books only; do not include web pages, text book or lab book, magazine etc.

Additional sources (e.g. newspaper or magazine article) acceptable but must have author(s) and date.

Initially the embedded librarian was introduced to the entire class during a lecture session held the second semester week. The following week she gave a presentation to each of the three lab sections during the last forty-five minutes of the two hour and fifty minute lab sessions. Her presentation introduced Bernard Lonergan's Generalized Empirical Method, and asked and addressed the specific topics: "why include scholarly sources", "what are scholarly sources", "how to incorporate scholarly sources into your lab report" and "how to cite scholarly sources". The librarian also explained the grading rubric, including its relationship with the four elements of GEM, as outlined in Table 1. The presentation concluded with a live demonstration of how to search online library resources effectively, limit results, and save and cite sources. This was followed with a 10 to 15 minute practice and question period. The librarian introduced individual databases, such as ScienceDirect, but focused mainly on using the library's Discovery Service (see Rose-W \& Hofmann, 2013). The presentation was supported by a step-by-step tutorial using a PowerPoint ${ }^{\circledR}$ presentation posted to a course research guide designed by the 
librarian and to the University's course management system, currently Blackboard. The librarian emphasized that the purpose was to improve students' understanding of the research process and help them to find and use scientific literature effectively.

In the subsequent lab session, the students conducted experiments on algal growth and the responses of protozoa to nutrients. The librarian revisited each of the three lab sections to reiterate key points and search tips in preparation for the first of five lab reports that would be due the following week. She also encouraged any students who had questions, or who were uncomfortable raising them in the lab, to contact her. The following week the students handed in two copies of their lab reports, one for the TA's to grade according to their rubric and one for the librarian to grade the four referencing components according to her rubric (Figure 1). For the remainder of the semester, the librarian visited each lab during the final 10-20 minutes to return copies of the completed lab reports with her scoring of and comments on the references, provide feedback on performance and problems, give or reiterate search or citation tips, answer any questions, and collect the next set of completed lab reports for scoring. After scoring all the final lab reports, fifth of five, the librarian visited the entire class to give a summative report on their information literacy progress and encourage students to continue the good habits that they had learned into subsequent classes.

\section{$\underline{\text { Second Iteration: Fall } 2014}$}

The authors felt the initial implementation of the ATM project had benefited students taking the General Biology course in the spring of 2014. Thus they again sought to facilitate learning in information literacy by using this model in the subsequent fall term, when the majority of first year students take General Biology. For fall 2014, the General Biology course had 2 lecture sections and 17 laboratory sections, with a total enrollment of 287 students (Table 2). This represented over a 500\% increase in enrollment from the previous introduction to the information literacy GEM project. Since many laboratory sections ran concurrently in two adjacent rooms, the librarian chose to give some presentations at the midpoint of the lab session and others during the last 45 minutes. Due to the large volume of lab 
PREPRINT: Enhancing information literacy using Bernard Lonergan's Generalized Empirical Method

sections, it was not feasible for the librarian to visit all sections similar to the previous terms and score all of the lab report references herself. Instead, she trained the ten graduate TA's to incorporate the reference rubric and scores into their rubrics for the overall lab reports To help control for consistency of TA grading, the librarian scored the references section for a sample of 66 lab reports from 11 of the 17 lab sections. Her scores were compared with the TA scores, and she subsequently reviewed the scoring process with them and provided general feedback and tips for the TA's to deliver to students in their respective sections. The librarian attended most of mandatory weekly TA meetings to monitor progress of the ATM project information literacy outcomes as reported by the TA's. She also visited the two main lecture sections at the midpoint and end of the term to provide direct student feedback and encouragement. While this clearly differed from the deep immersion and weekly sessions that the librarian offered during the spring, it did enable her to remain engaged with the course and gather some comparative data about student outcomes.

\section{Third Iteration: Spring 2015}

For the spring 2015 term, the authors again applied their ATM to three lab sections of General Biology, with an enrollment of 49 (Table 2). The librarian repeated the methodology used in spring 2014, with some minor changes implemented. First, the number of formal lab reports was reduced from five to four, with another assignment subsequently being omitted because of weather-related university closings. The librarian once again graded the reference section of the three lab reports in all three sections. However, a revised rubric was created when the first two authors collaborated with author 3, another Praxis fellow. The new grading rubric was refined to be clearer and more rigorous, raising the requirement for a perfect score to reflect a new anchor definition: "exceeds expectations" (Figure 2). This updated grading rubric accorded well with SHU'S increased focus on assessment and academic excellence. 
PREPRINT: Enhancing information literacy using Bernard Lonergan's Generalized Empirical Method

Figure 2: Revised Reference Grading Rubric for Biology 1212, Spring 2015

\begin{tabular}{|c|c|c|c|c|}
\hline Grading aspect & Exceeded expectations 1 & Good 0.8 & Satisfactory 0.6 & $\begin{array}{l}\text { Need significant } \\
\text { improvement }<=0.4\end{array}$ \\
\hline $\begin{array}{l}\text { Number and quality of } \\
\text { scientific sources }^{1} \\
\text { (Experience) }\end{array}$ & $\begin{array}{l}>3 \text { scholarly sources OR } \\
3+\text { scholarly sources plus } \\
\text { appropriate additional } \\
\text { sources }{ }^{2} \text { (excluding text } \\
\text { and/or lab manual) }\end{array}$ & $\begin{array}{l}3 \text { appropriate scholarly } \\
\text { articles; no } \\
\text { additional sources (excluding } \\
\text { text and/or lab manual) }\end{array}$ & $\begin{array}{l}2 \text { appropriate scholarly } \\
\text { articles, may include } \\
\text { additional sources }\end{array}$ & $\begin{array}{l}\text { One or no appropriate } \\
\text { scholarly articles (score } \\
\text { zero if none) }\end{array}$ \\
\hline $\begin{array}{l}\text { Relevance of sources } \\
\text { (Understanding) }\end{array}$ & $\begin{array}{l}>3 \text { sources relevant to } \\
\text { the question OR } 3 \\
\text { extremely relevant } \\
\text { sources }\end{array}$ & 3 relevant sources & 2 relevant sources & $\begin{array}{l}\text { 1-0 relevant sources } \\
\text { (score zero if nonel) }\end{array}$ \\
\hline $\begin{array}{l}\text { Integrating the references } \\
\text { (Judgment) }\end{array}$ & $\begin{array}{l}\text { all citations are well- } \\
\text { integrated }\end{array}$ & 3 citations well-integrated & $\begin{array}{l}2 \text { citations well- } \\
\text { integrated }\end{array}$ & $\begin{array}{l}1-0 \text { sources well } \\
\text { integrated (score } 0 \text { if } \\
\text { none) }\end{array}$ \\
\hline Citations (Action) & $\begin{array}{l}\text { all citations listed } \\
\text { correctly in reference list } \\
\text { and all references } \\
\text { correctly cited in } \\
\text { text, any quotations or } \\
\text { images }{ }^{3} \text { correctly } \\
\text { attributed, proper } \\
\text { citation style }\end{array}$ & $\begin{array}{l}\text { all citations referenced and } \\
\text { quotations/images } \\
\text { attributed; } 1-2 \text { citation errors } \\
\text { such as missing or incorrect } \\
\text { date, author, title or journal; } \\
\text { may have minor errors of } \\
\text { style }\end{array}$ & $\begin{array}{l}\text { In text citation with no } \\
\text { reference or vice versa, } \\
\text { or other significant } \\
\text { citation errors }\end{array}$ & $\begin{array}{l}>\text { two omissions and/or } \\
\text { direct quotation with no } \\
\text { attribution; major } \\
\text { citation errors ( } \mathrm{score} \\
\text { zero for plagiarism) }\end{array}$ \\
\hline
\end{tabular}

${ }^{1}$ Articles or scholarly books/book chapters; excludes web pages, text or lab book, magazine etc. Reports require at least 3 scholarly sources.

${ }^{2}$ Additional sources include newspaper or magazine, reputable website (e.g. .gov, or .edu) conference proceedings; all need author(s) and date.

${ }^{3}$ Images must be cited just like quotations.

Fourth Iteration: Fall 2015

During the summer of 2015 the three authors evaluated the effectiveness of prior information literacy efforts and collaboratively worked on revisions designed to improve delivery and student outcomes prior to the start of the large fall 2015 cohort. They felt that the class needed more contact with and reinforcement from the librarian, but time was a constant limitation, especially in the fall semester with the larger number of students and the offering of concurrent laboratory sessions. In response, the librarian developed online resources, assignments, and opportunities for assessment to supplement her physical presence in the classroom.

Specifically, the librarian in conjunction with the other authors, revised the course research guide and added supporting materials, such as "finding sources for your lab report", "how to read a scientific paper", "six habits of successful scientists", "avoiding plagiarism" and "citing sources" as well as the 
PREPRINT: Enhancing information literacy using Bernard Lonergan's Generalized Empirical Method

script and PowerPoint for the library presentation. The team expanded the introduction to Bernard Lonergan and GEM in the presentation, and included online background materials to improve the context of the philosophical and practical framework. The authors created an online "pre and post" assessment of students' self-perceived information literacy skills to be delivered electronically on Survey Monkey® prior to the initial library session and again at the end of the semester. The pre and post-test questions are listed in Table 3 and will be discussed in more detail in the Outcomes and Discussion sections of this manuscript. The librarian also developed three library exercises that focused on key skills, which earlier lab reports suggested students struggled to master (distinguishing among source types, recognizing where to insert a citation, and extracting key points from a quotation) for completion in Blackboard after the library presentation and before the first lab report. The authors believed that providing the online activities would evoke positive responses from students, such as those reported by Jacklin and Robinson (2013).

In a related effort to make the embedded librarian role more sustainable, the authors initiated a "train the trainer" approach, based on the methodology of Hartman et al., (2014). The librarian conducted a more formalized ninety-minute information session with the 11 graduate TA's assigned to lead the laboratory sessions. During this session, the librarian introduced and discussed Bernard Lonergan and GEM, reviewed the lab report requirements, the library research guide and the supporting documents. As in the previous fall, the TA's agreed to incorporate the reference rubric (Figure 2) into their lab report rubric. The TA's were to instruct all students in their assigned sections to complete the library skills pretest, which the librarian had posted to Blackboard, in the week prior to the library session. (The librarian distributed the library skills post-test through Blackboard during the final week of labs.) Furthermore, the authors wanted to encourage development of the TA's, and thus invited the 7 TA's who had charge of two lab sections to give the second library presentation themselves with the librarian standing by for support. Unfortunately, only two of them felt confident enough to do so. This observation was consistent 
with previous reports that graduate students themselves often struggle with information literacy, and therefore are reluctant to cover these topics with undergraduate students (Gregory, 2013; Lantz, 2016).

In designing the additional materials and exercises for fall 2015, the team also faced changes made to the biology course itself. Previously, the lecture and lab sections of General Biology 1201 were designed as a single four-credit course. In this term the General Biology lecture was split off into separate three-credit lecture session, and the laboratory component (renamed BIOL 1212) became a separate one-credit course. There were 18 laboratory sessions (one more than the previous fall term) with a total of 309 students enrolled (Table 2). The librarian delivered 16 of the library sessions and two TA's each delivered one.

The new stand-alone laboratory classes had a 20-minute reduction in the time allotted for each lab session compared to the previous semesters. As a result, the time allotted for the embedded librarian was correspondingly reduced to 20-30 minutes, leaving little time for questions and hands-on practice. The librarian briefly explained the three newly added library exercises, which the students were to submit on Blackboard at least a week before their first lab report was due. This new strategy, i.e. the librarian assigning and grading the information literacy exercises on Blackboard, saved time and allowed her to give better individual as well as group feedback. Students who initially did poorly were encouraged to resubmit, as the main goal of the exercises was to improve their ability to complete their lab reports successfully. The lab reports were still submitted in paper format to the TA's, who subsequently provided sample reports for the librarian to review and maintain a sense of student outcomes. The librarian visited the weekly labs in rotation during the semester, but typically there was little time available for questions and discussion. In an effort to compensate for the reduced lab time, the librarian frequently directed students to the online course research guide and, at the suggestion of a prior graduate of the course, scheduled two drop-in lab report assistance sessions. These ninety-minute sessions were designed to address any questions that students had about their lab reports, allow the guided practice that 
had not been possible during the reduced laboratory time, and facilitate a better understanding of the research process and scientific literature.

\section{Iteration 5: Spring 2016}

The authors employed the ATM project again in the spring 2016 semester. There were three lab sections, for a total of 46 students (Table 2). Many of the strategies that were developed or refined from the previous fall term were used on this much smaller group. These included the supporting materials, the three library exercises, and the pre and post-skills self-test. A new annotated bibliography assignment was added this semester. One of the long-standing course assignments was to make two oral presentations ("recitations") on a course-related topic. Although students were required to cite the sources that informed their recitations, there was no formal requirement for them to develop a research question, incorporate scholarly articles, or explain their choice of sources. The librarian had noted that many recitations were poorly researched and that the majority relied heavily or exclusively on popular web sources. She therefore assigned two annotated bibliographies, each to be submitted and graded prior to the recitation, in order to further develop the students' experience with research and improve the quality of the recitations.

The librarian distributed the library skills pre-test prior to the initial library presentation via the Survey Monkey tool. She gave a presentation (essentially the same as in the previous semester) to all three lab sections. Due to time constraints, the session was abbreviated for Section A and reduced to a very brief demonstration in Section B. Section C received the full presentation as previously given, although again there was no time for guided practice. The librarian directed students to the supporting materials on the course research guide and explained the three library exercises that she would be grading, as in the previous semester. The librarian visited each of the labs on most subsequent weeks, inviting questions and discussion when time permitted. 
To meet the goals of the ATM project more effectively, students were required to submit their laboratory reports and annotated bibliographies, well as the library exercises electronically through Blackboard. This new practice freed the librarian from physically collecting copies of the lab reports from the TA's and returning them individually to students during laboratory class time. It also allowed her to post comments and grades electronically. As in the spring 2015 semester, the librarian graded the referencing portions of the four formal lab reports in accordance with the revised reference rubric (Figure 2) as well as the two new annotated bibliography assignments. To capture changes in students' perceptions about their information literacy, a Blackboard announcement and an email with a link to the library skills post-test were sent to students during the final week of labs.

\section{Outcomes of applying the method: a three year exploration}

The authors' presentation of the ATM project development over the five semesters illustrates how three diverse faculty can collaborate to address a significant concern of information literacy within a biology course. Using the philosophy of Bernard Lonergan, they themselves engaged in the GEM process, i.e., experience, understanding, judgment, and action to utilize pedagogical strategies to enhance learning with an embedded librarian participating in laboratory-based sessions. One requirement for the Praxis ATM project included developing assessments for the participants to judge if change in the students thinking and learning occurred. The intent of the measurements was to capture student progress throughout a course as well as any course feedback that may have been generated. All ATMs were designed as classroom initiatives and not as formal research-based endeavors.

The authors' observations are presented on a semester by semester basis for each cohort of students enrolled. For the three spring semesters, their ATM development was informed by comparative grades for the reference portions of the laboratory reports, which were consistently graded by the librarian, and (in spring 2016) by the grades she gave the annotated bibliographies. However, this was a pedagogical exploration and not an experimental study in which the many variables affecting student performance could be controlled, so these quantitative results must be interpreted with caution. 
Laboratory report grades for the two fall semesters were not included because numerous TA's were responsible for the grading. Across all five semesters the authors relied heavily on their qualitative impressions of the students' work as well as feedback from the TA's and the students themselves, to evaluate student outcomes. The most noticeable outcomes were increased use of scholarly articles versus open web sources, better integration and citation of sources, and greater comfort and familiarity with engaging the scholarly literature.

For the first iteration of this ATM project in the spring 2014 semester, the on-time submission of the five formal lab reports averaged $64 \%$, with a low of $48 \%$ for report four (Table 2). The average reference score across the three lab sections increased by $25 \%$, from $73 \%$ for the first lab report to $91 \%$ for the final report (Figure 3, all sections bar graph). There was some variation in improvement among lab sections, but the average score for each section increased, especially section $\mathrm{C}$ where the lowest initial score occurred Average scores for each of the four reference elements also increased over the five reports (Figure 4, lab report scores by element bar graph). The most substantial increases were in the quality of sources (using peer-reviewed articles rather than magazines or websites) and the integration of the articles into the lab report. Students' use of websites that were clearly obtained from Google decreased from $29 \%$ to $10 \%$, which the authors saw as a very positive improvement.

In the fall 2014 semester time constraints prevented the librarian from collecting and grading four lab reports from 17 sections, but she took a random sample of 66 of the second formal lab reports to compare with those from the spring semester. The fall 2014 sample showed similar results to those from spring 2014, with average scores of $83 \%$ compared with $85 \%$.

In the third iteration of the ATM project (spring 2015) the average on-time submission for the three lab reports increased to $86 \%$, (Table 2), although the rate fell to $65 \%$ for report 3 . The average reference score for the three lab sections increased by $24 \%$, from $63 \%$ for the first lab report to $78 \%$ for the final report (Figure 5, all sections bar graph). The average scores for the first two lab reports were 
Figure 3: Spring 2014, average lab report scores by section

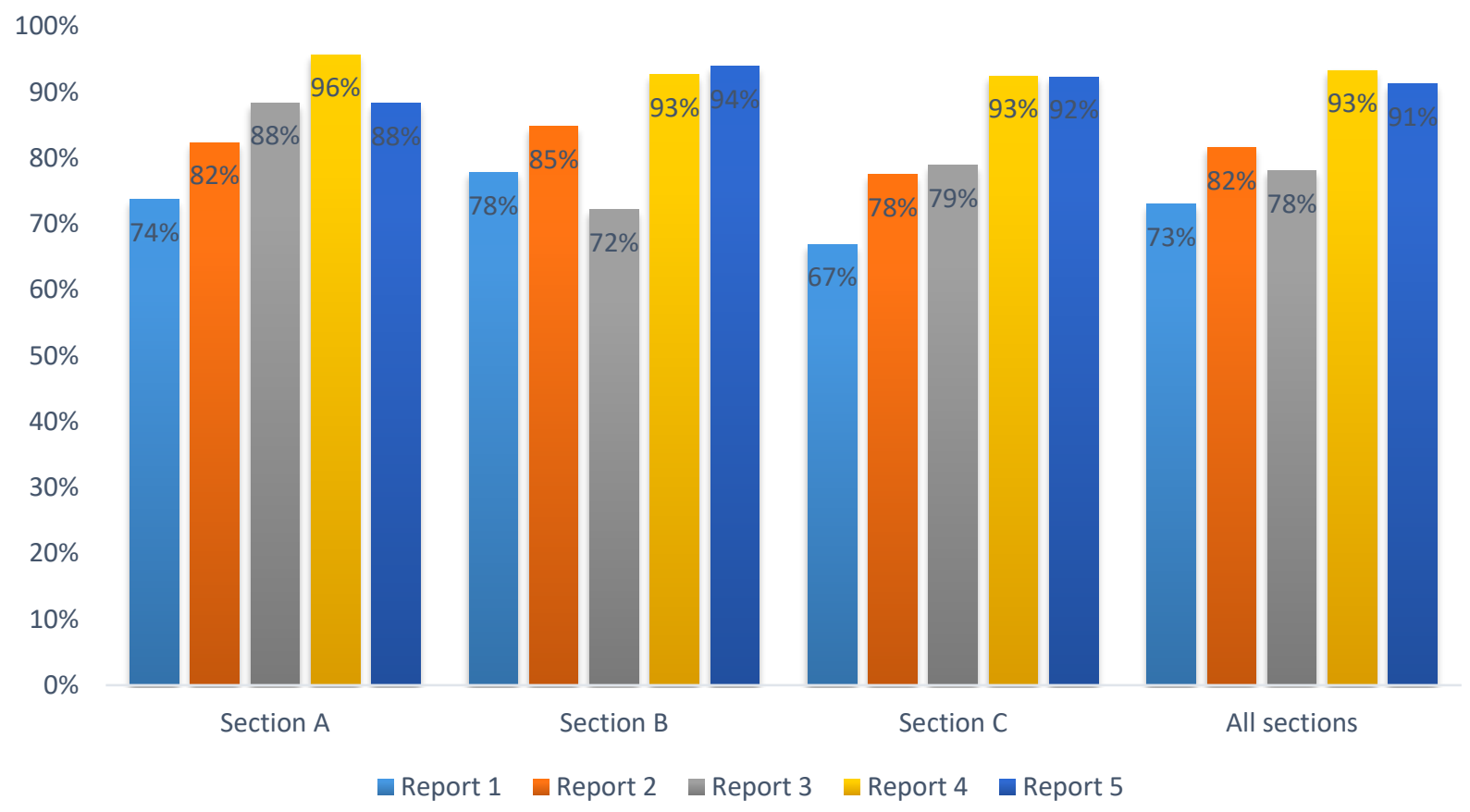

Figure 4: Spring 2014 lab report scores by element

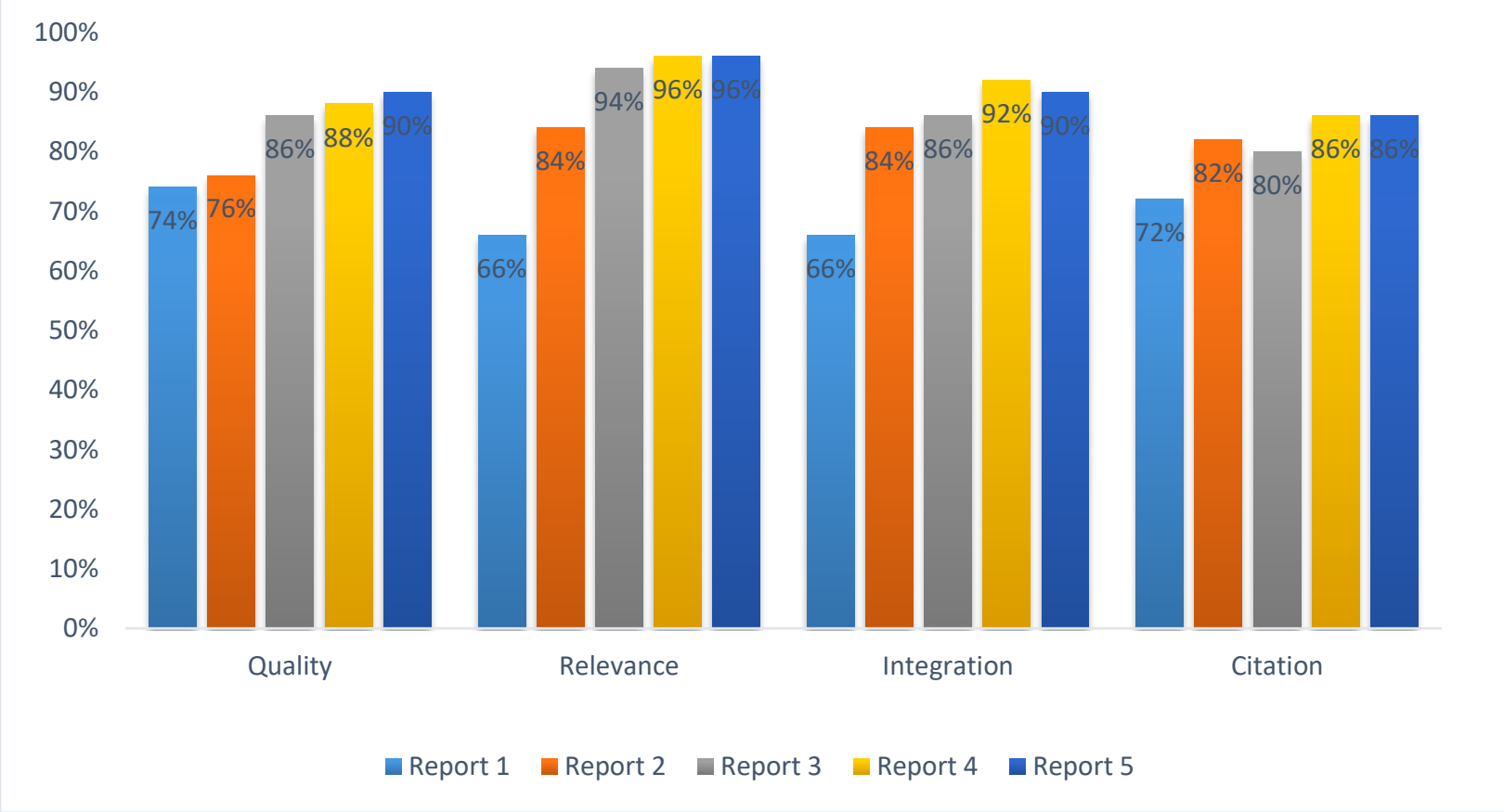


Figure 5: Spring 2015, average lab report scores by section

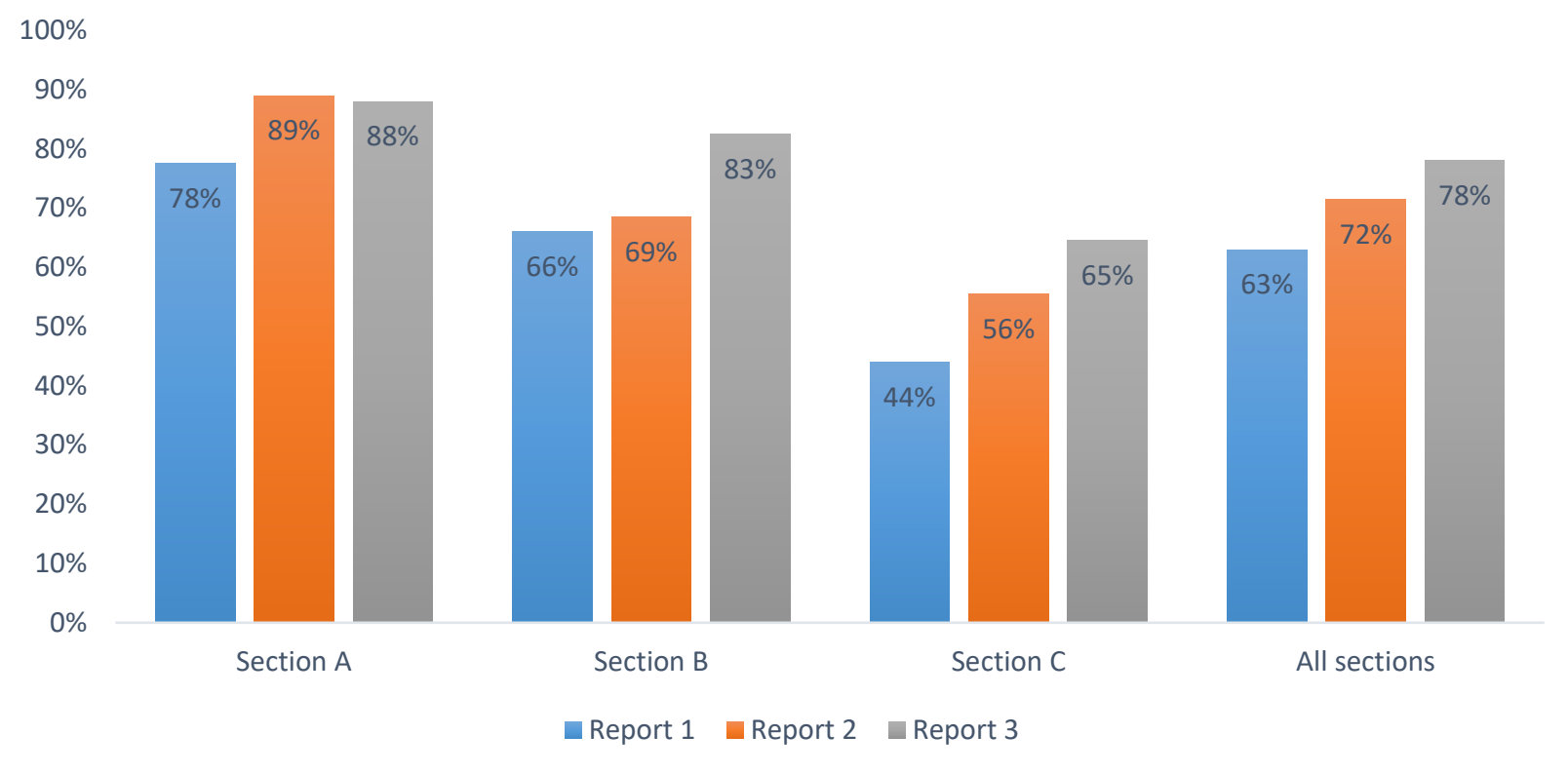

Figure 6: Spring 2015, average lab report scores by element

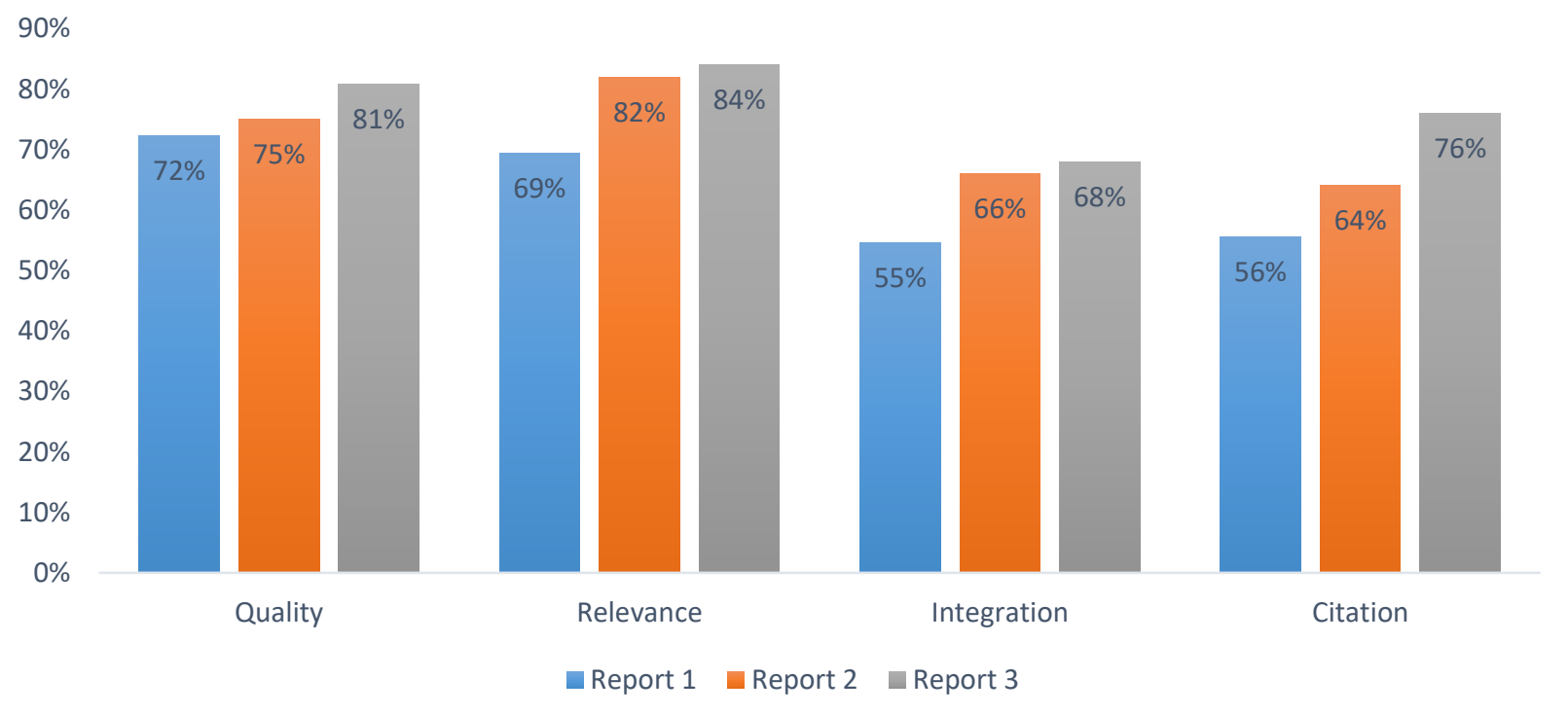


lower than in spring 2014, largely due to the increased rigor of the grading rubric. However, the average score for the third (final) lab report was the same as in the spring 2014 semester, with a similar $24 \%$ increase from the initial lab report (Figure 5). There was some variation in improvement among lab sections, but the average score for each section increased, especially section $\mathrm{C}$ where once again the lowest initial score occurred. Scores for all four elements increased from report one to report three, with the greatest increase noted in the correct citation of sources (Figure 6, lab report scores by element). The increases were modest compared with spring 2014 but they were consistent across the three sections. Students' use of websites clearly obtained from Google decreased dramatically, from $40 \%$ to $6 \%$.

In fall 2015, a sample of 140 lab reports (35 from each of the four assigned reports) had similar average scores and showed a similar pattern to the spring, with a modest $11 \%$ average improvement over the four reports. The greatest improvements were in the relevance and citation of sources. However, some students voiced concerns and confusion about the lab reports and responded positively to the librarian's suggestion for informal drop-in help sessions. After receiving 66 responses to an online survey suggesting a variety of time slots, the librarian offered two 90-minute drop-in lab report assistance sessions in the evenings, which were overwhelmingly the most popular time selected. The sessions were led by a graduate of an earlier Biology 1212 class, assisted by the librarian. Actual attendance was low: seven students attended the first session and eight attended the second. However, most students stayed for the entire period and 13 completed a brief survey about the extra session. All indicated that the session was helpful, and nine (69\%) indicated that it was "very" or "extremely" helpful.

The completion rate for the three newly added library exercises posted to Blackboard was $77 \%$, and the average score for students who completed them was $89 \%$. There was a $68 \%$ response rate (210/309) on the library skills pre-test, which the TA's asked the students to complete before the librarian's presentation. There was a $45 \%$ response rate on the post-test, which both the librarian and the TA's asked them to complete at the end of the semester. The students' assessment of their library skills increased modestly from the pre-test to post-test, with the largest increase in those who "strongly agreed" 
or "agreed" that they knew how to use search limits such peer-reviewed or full text, and how to search individual databases such as ScienceDirect (Table 3). A notable exception to the increase in confidence was selection of appropriate keywords, which decreased from $81 \%$ to $67 \%$. On the post-test, $65 \%$ of students thought the library presentation was "extremely helpful" or "somewhat helpful" and 54\% thought the library exercises were helpful (Table 3).

Table 3: Fall 2015 Library Skills Survey Summary Results

\begin{tabular}{|c|c|c|c|c|c|}
\hline & \multicolumn{2}{|c|}{ Pre Test $(n=210)$} & \multicolumn{2}{|c|}{ Post Test $(n=142)$} & \multirow[b]{2}{*}{$\begin{array}{c}\text { agree } 96 \\
\text { change }\end{array}$} \\
\hline Question & \% disagree & $\%$ agree & \% disagree & \% agree & \\
\hline I can write a good research question & $15 \%$ & $42 \%$ & $20 \%$ & $54 \%$ & $12 \%$ \\
\hline $\begin{array}{l}\text { I can identify key words to search for information on my research } \\
\text { question }\end{array}$ & $5 \%$ & $81 \%$ & $17 \%$ & $67 \%$ & -149 \\
\hline I can do an advanced search using the box on the library home page & 2696 & $47 \%$ & $13 \%$ & $67 \%$ & $20 \%$ \\
\hline I understand what scholarly sources are & 996 & $68 \%$ & $14 \%$ & $74 \%$ & $6 \%$ \\
\hline $\begin{array}{l}\text { I know how to limit SHUsearch results by subject, peer-reviewed and } \\
\text { full text }\end{array}$ & $33 \%$ & $44 \%$ & $15 \%$ & $69 \%$ & $25 \%$ \\
\hline $\begin{array}{l}\text { I know how to find and search specific databases such as } \\
\text { ScienceDirect }\end{array}$ & $43 \%$ & $33 \%$ & $22 \%$ & $53 \%$ & $20 \%$ \\
\hline $\begin{array}{l}\text { I know how to find the full text of an article when I only see the title } \\
\text { or abstract }\end{array}$ & $28 \%$ & $46 \%$ & $23 \%$ & $56 \%$ & $10 \%$ \\
\hline $\begin{array}{l}\text { I khow how to evaluate the reliability of online sources such as } \\
\text { websites }\end{array}$ & 139 & $57 \%$ & $15 \%$ & $68 \%$ & 1196 \\
\hline I know how to find an article from a citation & $11 \%$ & $51 \%$ & $19 \%$ & $56 \%$ & $5 \%$ \\
\hline I know how to cite references in the body of a lab report & $21 \%$ & $50 \%$ & $16 \%$ & $65 \%$ & $15 \%$ \\
\hline I know how to cite sources on a list of references cited & 2296 & $50 \%$ & $15 \%$ & $65 \%$ & 1496 \\
\hline I feel comfortable using the library and its resources & $17 \%$ & $49 \%$ & $17 \%$ & $57 \%$ & $8 \%$ \\
\hline Post-test only questions & & & helpful & Not helpful & \\
\hline How helpful was the librarian presentation? & & & $65 \%$ & $17 \%$ & \\
\hline How helpful were the library exercises? & & & $54 \%$ & $20 \%$ & \\
\hline
\end{tabular}

In the fifth iteration of the ATM project (spring 2016), on-time submission of the four formal lab reports averaged $79 \%$, somewhat less than the previous year (Table 2). The average reference score for the three lab sections increased by $25 \%$, from $58 \%$ for the first lab report to $74 \%$ for the fourth and final report (Figure 7, all sections bar graph). There was some variation among lab sections, but the average score for each section increased, especially for section A, which had the lowest initial score (Figure 7). Average scores for each of the four rubric elements increased slightly, with the exception of citation style (Figure 8). Section C, which received a full presentation from the librarian, had the highest scores on all four lab reports. The average scores for sections A and B in spring 2016 were consistently lower than in 
spring 2015. For example, in spring 2016 Section A had an average score of $45 \%$ for the first lab report compared with $78 \%$ in spring 2015 and Section B scored an average of 58\% compared with $66 \%$ in spring 2015 (Figure 5, Figure 7). This suggests that the lack of a full library presentation in those sections had a negative impact, likely exacerbated by the reduced in-person contact time with the librarian.

The average completion rate for the library exercise and average score for those completing the exercises were both $86 \%$, similar to the results for fall 2015 . The completion rates for the two annotated bibliographies were $87 \%$ and $77 \%$ respectively, and the average scores were $85 \%$ and $78 \%$. The lower score on the second bibliography reflects a combination of more stringent grading, particularly regarding proper citation style, and a lower completion rate. Overall the annotated bibliographies were very well done, and the TA's reported that the oral recitations were far better than in previous years.

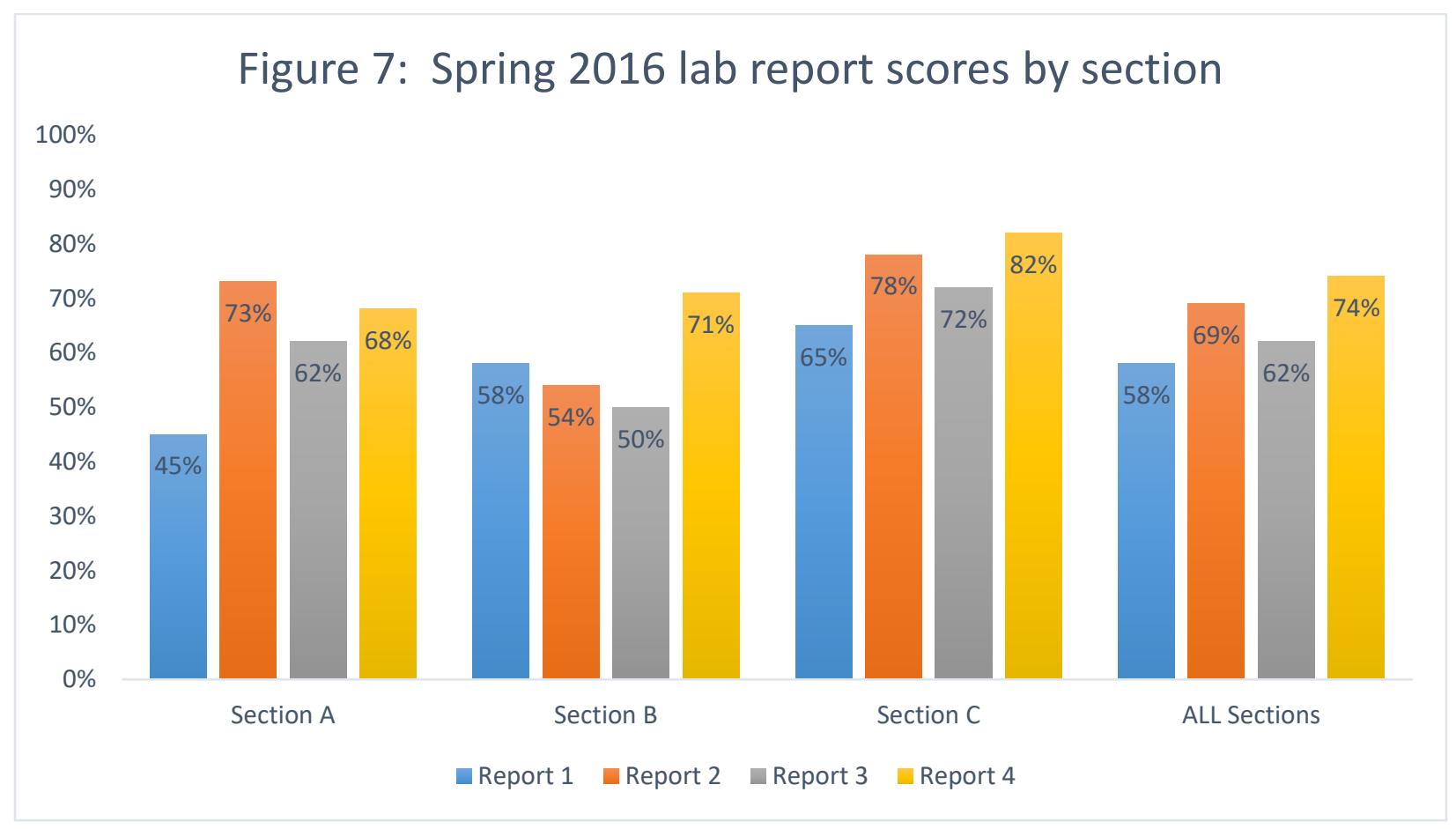




\section{Figure 8: Spring 2016, average lab report scores by element}

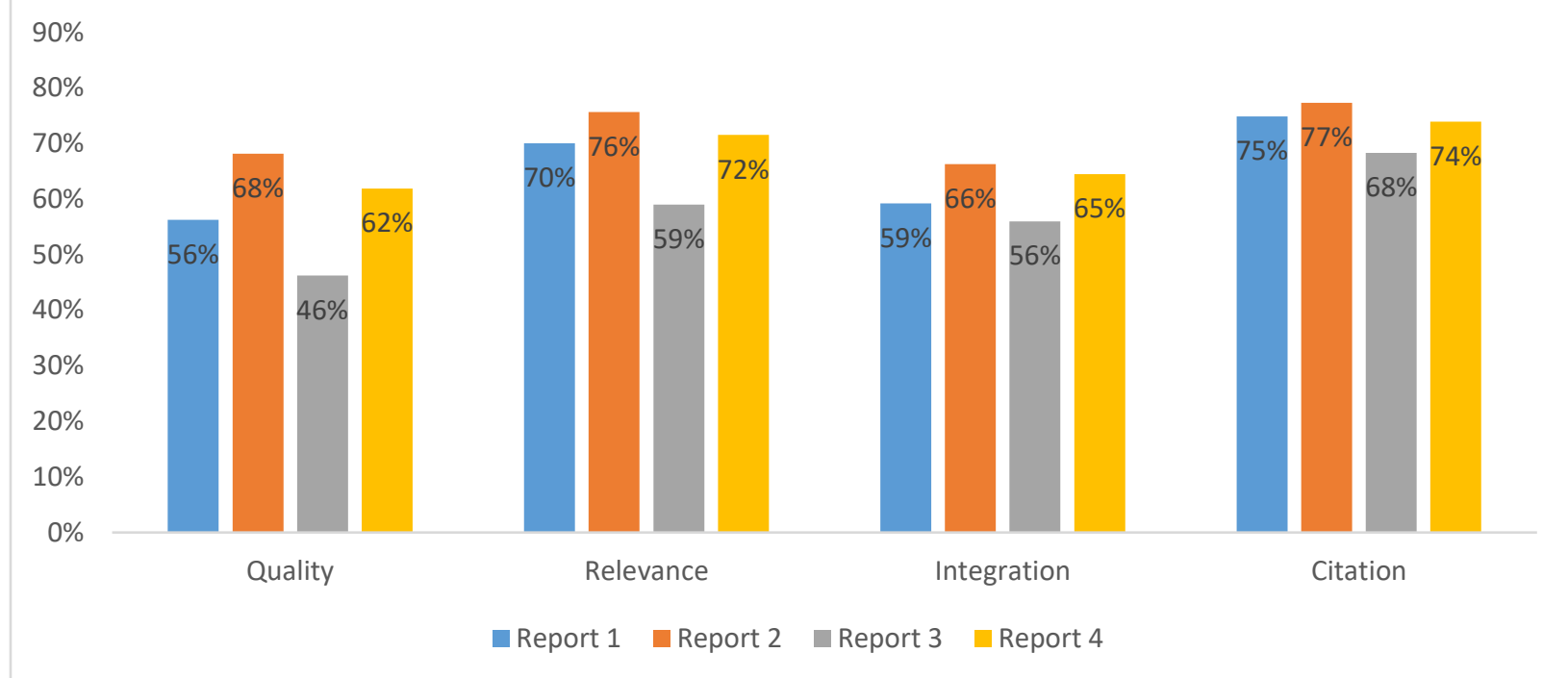

The response rate on the library skills pre-test was $80 \%$ (37/46) and the response rate on the library skills post-test was $41 \%$ (19/46). Based on this small sample, students' assessment of their library skills increased from the pre-test to post-test, with the largest increase in those who strongly agreed or agreed that they knew how search individual databases such as ScienceDirect and how to cite sources

(Table 4). The smallest increase was in percentage of students who agreed that they could identify good keywords. Only $42 \%$ of the students who responded thought the library presentation was helpful, compared with $65 \%$ in the fall, and only $25 \%$ thought the library exercises were helpful compared with $54 \%$ in the fall.

The librarian examined the usage statistics for the course research guides during the five semesters of the ATM collaboration. The average was about one view per student for the first three semesters, 2.3 per student in fall 2015 and 2.4 in spring 2016 (Table 5). The exception was in fall 2014, 
when there were technical difficulties associated with migrating the library research guides to a new

Table 4: Spring 2016 Library Skills Survey Summary Results

\begin{tabular}{|c|c|c|c|c|c|}
\hline \multicolumn{3}{|c|}{ Pre Test $(n=37)$} & \multicolumn{2}{|c|}{ Post Test $(n=19)$} & \multirow[b]{2}{*}{$\begin{array}{c}\text { agree \% } \\
\text { change }\end{array}$} \\
\hline Question & \% disagree & \% agree & \% disagree & \% agree & \\
\hline I can write a good research question & 1096 & $31 \%$ & $0 \%$ & 6396 & $32 \%$ \\
\hline $\begin{array}{l}\text { I can identify key words to search for information on my research } \\
\text { question }\end{array}$ & $0 \%$ & $74 \%$ & $0 \%$ & 7996 & $5 \%$ \\
\hline $\begin{array}{l}\text { I can do an advanced search using the box on the library home } \\
\text { page }\end{array}$ & $8 \%$ & $64 \%$ & $5 \%$ & 7996 & $15 \%$ \\
\hline I understand what scholarly sources are & $8 \%$ & $74 \%$ & $5 \%$ & 8496 & $10 \%$ \\
\hline $\begin{array}{l}\text { I know how to limit SHUsearch results by subject, peer-reviewed } \\
\text { and full text }\end{array}$ & $18 \%$ & $64 \%$ & $5 \%$ & $79 \%$ & $15 \%$ \\
\hline $\begin{array}{l}\text { I know how to find and search specific databases such as } \\
\text { skienceDirect }\end{array}$ & $46 \%$ & $33 \%$ & $11 \%$ & 7996 & $46 \%$ \\
\hline $\begin{array}{l}\text { I know how to find the full text of an article when I only see the title } \\
\text { or abstract }\end{array}$ & 1896 & $51 \%$ & $11 \%$ & 7996 & $28 \%$ \\
\hline $\begin{array}{l}\text { I know how to evaluate the reliability of online sources such as } \\
\text { websites }\end{array}$ & $18 \%$ & $59 \%$ & $11 \%$ & 7496 & $15 \%$ \\
\hline I know how to find an article from a citation & $23 \%$ & $56 \%$ & $0 \%$ & $79 \%$ & $23 \%$ \\
\hline I know how to cite references in the body of a lab report & 2696 & $46 \%$ & $5 \%$ & 8496 & $38 \%$ \\
\hline I know how to cite references on a list of references cited & $15 \%$ & $59 \%$ & $5 \%$ & 7496 & $15 \%$ \\
\hline I feel comfortable using the library and its resources & $10 \%$ & $62 \%$ & $11 \%$ & 6896 & $7 \%$ \\
\hline Post-test only questions & & & helpful & not helpful & \\
\hline How helpful was the librarian presentation? & & & $42 \%$ & $26 \%$ & \\
\hline How helpful were the library exercises? & & & $25 \%$ & $42 \%$ & \\
\hline
\end{tabular}

version of the SpringShare platform. In fall 2015 the views were concentrated in September $(n=209)$ and October $(n=390)$, closely following the library presentation during the week of September $22^{\text {nd }}$. The views were spread more evenly throughout the semester in spring 2016, but in both semesters about two thirds of the views were limited to the first page of the guide.

Table 5: Views of General Biology Course Research Guide, Spring 2014-2016

\begin{tabular}{|l|c|c|c|c|c|}
\hline Semester & Total Views & Students & average & 1st page & $\begin{array}{l}\text { 2nd } \\
\text { page }\end{array}$ \\
\hline Spring 2014 & 55 & 52 & 1.1 & $49 \%$ & $15 \%$ \\
\hline Fall 2014 & 37 & 287 & 0.1 & $51 \%$ & $16 \%$ \\
\hline Spring 2015 & 45 & 49 & 0.9 & $29 \%$ & $27 \%$ \\
\hline Fall 2015 & 696 & 309 & 2.3 & $65 \%$ & $20 \%$ \\
\hline Spring 2016 & 112 & 46 & 2.4 & $64 \%$ & $21 \%$ \\
\hline
\end{tabular}




\section{Discussion}

The implementation of the authors' combined ATMs in the three spring semesters of a first year General Biology Laboratory course suggest that having an embedded librarian improved student outcomes in information literacy. Average grades for the quality and use of references in the formal lab reports increased by about $25 \%$ in each of semester. This contrasts with the findings of Douglas and Rabinowitz (2016), who reported no correlation between faculty-librarian collaboration and students' use of sources in research essay assignments. It is unclear how much of the improvement in scores was due to the librarian's intervention and how much was due to students simply improving with practice.

Another confounding factor was the librarian's tendency to grade subsequent lab reports more stringently than the initial report. Thus, the authors reiterate that the improvement in scores must be interpreted with caution.

The authors found the qualitative impressions of the laboratory TA's and the class instructor, as well as the librarian, to be the most significant outcomes. All felt that the overall quality of the lab reports and the students' selection and use of references improved markedly over the course of each semester. More significantly, these students produced much better lab reports than those enrolled in other biology classes did. At a spring 2015 meeting, one graduate student teaching assistant remarked that the students submitted better papers than second and third year biology students, to which several other TA's agreed. Many of the TA's said that they themselves had learned a lot from the librarian; several expressed regret that they had not received similar help during their undergraduate years. Indeed, one advantage of the librarian's involvement with the course was the opportunity for graduate student TA's to improve their information literacy, which in turn improves their ability to effectively instruct undergraduates (Lantz, 2016). Several TA's also commented that they had found the GEM framework helpful in doing their own research and writing. 
Two rarely reported advantages of having a librarian grade the use of information sources in written assignments are experience and consistency. Large introductory biology classes typically rely on multiple teaching assistants and/or adjuncts to conduct laboratory sessions and grade lab assignments (Lantz, 2016). Masters' students in particular have little prior teaching experience and very demanding schedules. As previously noted, these graduate students often have poorly developed information literacy skills. In addition, having multiple instructors and TA's within one course inevitably results in inconsistencies in content delivery and grading rigor (Lantz 2016). The authors were confident that their rubric, particularly the revised version, was clear and unambiguous to use. However, there is a qualitative aspect to judging components such as the relevance, quality, and integration of sources. The absence of verified inter-observer reliability among the TA's was the prime reason for not including their lab report reference grades from the fall semesters in the project outcomes.

The heavy time demand of embedded librarianship is often noted in the literature (Arp et al., 2006; Abrizah et al., 2016). Finding time for library instruction in the busy lab session schedule was equally challenging. The librarian felt that more time for guided practice in the initial sessions and more reinforcement on return visits would have been beneficial. Gilbert (2009) stresses the advantages of repeated library instruction, although Beile (2003) reports that while education students' performance on library skills tests improved after a library instruction session, there was no significant effect of repeat sessions. In this project, the lower reference scores in spring 2016, particularly in sections A and B which had abbreviated library sessions, suggested that students benefited from the feedback and reinforcement provided by the librarian in earlier semesters where the lab periods were longer. The outcomes of the three spring semesters support Beile's (2003) conclusion that further research on the effects of repeated library instruction is warranted.

The comparison of the pre and post self-assessments of library skills collected in fall 2015 and spring 2016 provided mixed feedback. The students' perceived confidence with their research and their sense of comfort with the library generally increased between the pre and post-assessment times. This 
occurred especially with fall 2015 cohort, when the collected numbers on both pre and post-test sample was large. The notable exception was found with the statement: "I can identify key words to search for information on my research question”, which declined in fall 2015 semester and increased only marginally in spring 2016 term. This is consistent with previous observations that students often overrate their mastery of information literacy (Ferguson et al., 2006; Kim and Shumaker, 2015), especially in regard to selection of key words (Bloom \& Deyrup, 2015; Dalal et al., 2015; Dempsey \& Valenti, 2016). When searching key words in the academic databases, some students likely found their actual experience led them to understand that this aspect of the scientific process is far more difficult than they had thought.

The outcomes indicated that two-thirds of responding fall 2015 and about half of responding spring 2016 students said that they found the library sessions helpful or very helpful. This may be partly because the reduced lab time meant that practice with key word searching was lost in many of the 2015 sessions and all of the 2016 sessions. Comments such as "practicing searching for sources made my skills easier doing lab reports and finding scholarly sources" suggested that some students found the practice valuable. The embedded librarian had attempted to compensate for the reduced time by offering drop in help sessions in fall 2015, but the low attendance and the high time investment made it difficult to justify repeating them. This links with the findings of Freiburger et al., (2016), who report that open workshops with no reward, such as a course credit, resulted in poor attendance.

The authors noted disappointment in the poor response to the library sessions and exercises, especially with a decrease in positive responses between the fall 2015 and spring 2016 terms. The spring 2016 rate was very small $(n=19)$, and thus may not have been representative of the whole class.

However, the collective comments from the few students who included them in their feedback response as well as the embedded librarian's informal discussions with students suggest that time was a significant factor. The authors' results correspond with the observations that first year college students come with varying levels of experience and abilities in the scientific process, given the range of comments obtained on the post-assessments. While there were some positive comments, such as "my skills improved a lot, 
thank you", the negative comments on the post-test included "I already knew how to do those things and the library skills part was a waste of time" and (the librarian) is "not understanding all of the obligations of a biology major". The commentary aligns with informal discussions with the librarian. The embedded librarian found many students complained about time pressure and competing assignments, and admitted that they ignored materials posted online unless there were points associated with completing them. Jacklin and Robinson (2013) report a similar response from students. Instead of seeing the readings, PowerPoints and library exercises as ways to improve their lab reports and thus their grades, it seems that students saw these as "just more stuff to do". This dislike of perceived "busy work", noted by Weiler (2005), likely explains the low use of the library research guide and associated materials.

The students enrolled in these courses were surprisingly open in telling the librarian that they would spend little or no time on assignments that carried relatively few points and focused instead on more "valuable" assignments. This phenomenon was clearly reflected in the number of students who did not include any sources in their lab reports or simply did not do one or more of the reports at all. It was particularly noticeable in the spring 2016 sections, when ten of 46 students (22\%) failed to submit at least one lab report, and one student each who failed to submit two, three, or all four reports. The quality of some reports were also low, with six students (13\%) submitting at least one lab report with no references, and one student who submitted all four reports with no references.

Since it was separated from the lecture component in fall 2015, the Biology Laboratory course, BIOL 1212, became a one-credit course. The lab reports accounted for about $20 \%$ of the total grade and the reference components account for only $20 \%$ of a lab report grade, or about $4 \%$ of the total course grade. It is understandable that some students made a strategic decision not to invest time in a difficult exercise that has relatively low (grade) value. This is consistent with classic optimal foraging theory, which models gaining the most benefit for the least cost (Emlen, 1966; MacArthur \& Pianka, 1966; Schoener, 1971). The concept has been applied to information seeking on the (somewhat debatable) premise that information seekers make mathematically or ecologically rational decisions (e.g. Sandstrom, 
1994; Pirolli, 2007). When viewed from this perspective, perhaps it should have been a pleasant surprise that the majority of students did take time to incorporate scholarly articles in their lab reports.

Connaway et al., (2011) extend the rational choice model to include convenience as a major factor in information seeking behavior and choice of sources. The authors found convenience to be particularly important for "Millennials" or "Generation Y" (those born since 1981), but note that the priority of convenience crosses demographic boundaries. There have been numerous attempts to characterize Millennials, who comprise the majority of today's college students. A range of the more commonly subscribed traits include self-confidence, a sense of entitlement, reliance on technology, frequent multi-tasking, short attention span, expectation of immediate gratification, a preference for visual learning over reading, lack of critical thinking, and a consumerist attitude to education (e.g. Manuel, 2002; Weiler, 2004; Warwick et al., 2009; Bourke \& Mechler, 2010; Thaler, 2013). It has also been argued that Millennials come to college with a sense of their own entitlement, again referring to a consumerist attitude to education as a service, which they have paid for (Manuel, 2002; Fullerton, 2013; Knowlton \& Hagopian, 2013). A recurring comment is the importance of saving time, often at the expense of finding appropriate or accurate results. Such traits certainly do not fit well with the complex and often frustrating task of conducting scientific research, (Kuhlthau 1991; 2004) or with appreciating traditional library instruction.

Librarians and teaching faculty have often observed - and lamented - many of these traits in undergraduate students. However, the do not necessarily characterize an entire generation of college students or the majority of SHU undergraduate students. In a recent study of learning styles, Kirschner and van Merriënboer (2013) note that "the assumption that people cluster into distinct groups --- receives very little support from objective studies" (p. 173). Buschman (2007) argues that the construction of generational stereotypes or "generationalism" is a marketing tactic aimed at persuading libraries to invest in the latest technology and services in order to satisfy their Millennial "customers". Dungy (2011) makes a convincing argument that the stereotype does not fit most African American Millennials and that 
race, gender, class and economic status all play a role in shaping today's students. SHU traditionally enrolls many first generation college students and minorities, and increasingly a number of high achieving students who ranked among the top $10 \%$ of their graduating high school class. Dungy acknowledges the need for further research on (diverse) Millennials, but stresses the need to pay attention to "our own observations and to those of our colleagues, as well as the thoughts and feelings of students themselves" (p. 18). Reed and Thompson (2016) similarly advocate "reflection, student feedback and continued dialogue" between librarians and teaching faculty (p. 209).

Another important consideration is that students come to college with different levels of critical thinking ability and intellectual development (Weiler, 2005; Varlejs et al., 2014; Loesch, 2017). Many lack skill in time management and organization (Jacklin \& Robinson, 2013), as well as a lack of real understanding of online resources and the limitations of multi-tasking (Kirschner \& van Merriënboer, 2013). Teaching faculty may not appreciate the lack of experience in complex searching and understanding of results that characterize many first year students, forgetting or not understanding how they acquired their own skills and disciplinary knowledge (Leckie, 1996). In related terms, faculty also have individual differences in their approaches to research, problem solving, learning and all kinds of intellectual activity (Grallo, 2016).

When faced with challenging information seeking, students tend to fall back on known strategies such as using their text book, assigned readings or open web searches rather than using unfamiliar library databases. As Warwick et al., (2009) observe, they find it difficult to engage the scientific literature because they lack the ability to "assimilate and use the new information" (p. 2413). This resonates with the position of Lonergan (1993), who describe young students as “developing subjects" who need to appropriate knowledge and incorporate it into their own framework, using both their own upward development and the downward effect of expert instruction. Lonergan emphasizes that educators must "build on the foundations ... in the mind of the pupil" (p.104) in order to enlarge his or her horizons to encompass new knowledge, and notes that "fundamentally, any learning is an activity of the subject" (p. 
PREPRINT: Enhancing information literacy using Bernard Lonergan's Generalized Empirical Method

145). This is supported by more recent work that emphasizes the need for instructor guidance along with some autonomy in consideration of students' development level (Kirschner \& van Merriënboer, 2013; Zhang, 2016; see also Roscoe, 2004). Viewed from this perspective, the authors wondered whether it is reasonable to expect first year students to develop the skills needed to conduct complex library searches, understand and evaluate scientific articles and appreciate how to relate them to laboratory experiments and exercises. While the authors felt that their work with the students had been valuable, reflection on the overall experience led them to believe that a change in approach was needed.

\section{Lessons Learned and Revisions to the Course}

The purpose of this manuscript is to illustrate how a team of 3 faculty from different disciplines sought to increase select information literacy outcomes of first year biology students using Lonergan's GEM model. However, the authors wanted to use the results of their comingled ATM project to further improve the first year biology lab course and students' understanding of the research process and scientific literature.

Based on collected outcomes and feedback from this ATM project and broader departmental discussions, the Biological Sciences faculty decided to revise the General Biology curriculum substantially. This included eliminating the formal laboratory reports in favor of other learning activities. Although such reports are a common assignment in introductory biology laboratory courses, (Lantz, 2016), the authors embraced this as a positive change. This action allowed the embedded librarian to focus on guiding students to find, evaluate, and cite sources for the annotated bibliographies that formed the basis of two class presentations. Students worked in pairs on these projects and chose from a range of topics, or could propose their own topic for approval. The authors felt that students would be more engaged in conducting research for a topic they had chosen, engendering in them sufficient interest to wonder and ask questions (Marroum, 2004; Roscoe, 2004), rather than simply reporting on set experiments. In Lonergan's terms, these assignments gave students an opportunity to expand their horizons beyond the class laboratory and appropriate their own knowledge (Lonergan, 1993). In more 
pragmatic terms, the annotated bibliographies and presentations were assigned a much higher proportion of their grade than had been the references for the lab reports, which should have encouraged students to complete the assignments.

Another advantage of abandoning the formal laboratory reports was freeing time for the librarian to make the initial presentations longer and more interactive, and to expand on the GEM framework that previously was given little reinforcement. Feedback from previous semesters indicated that while some students found GEM helpful, others forgot about it after the initial presentation. It was clearly necessary to reinforce its relevance, not only for library research but also as a comprehensive framework for critical and reflective thinking. Lonergan's position on students as developing subjects needing time to appropriate knowledge was a valuable guide; one that emphasized not only the cognitive development of our students but also the vital role of engaging instruction that could meet students at their own level. Accordingly, it was decided to abandon the library exercises and additional readings, focusing instead on developing the core skills of finding and evaluating sources and understanding the scientific literature. To increase student engagement, the librarian incorporated an online "question and answer" game on the interactive learning platform "Top Hat" that focused on students identifying different source types and citation errors during the library presentation. The authors hoped that adding enjoyment as well as interaction would improve student attitudes to library instruction (Manuel, 2002).

\section{CONCLUSION}

The authors felt that their interdisciplinary ATM project that explored the concept of integrating an embedded librarian into an introductory biology laboratory course across several semesters was successful in improving first year students' understanding of the research process and scientific literature. Overall students demonstrated a better understanding of information literacy based upon our recorded outcomes and informal feedback. Grades for the student's selection, evaluation, integration, and citation of scholarly sources in formal laboratory reports improved by an average of $25 \%$ over the course of a semester. Graduate TA's felt that the first year students in these classes were writing better laboratory 
reports than their predecessors, and even students in higher level courses. The three-year experience also taught us valuable lessons in pedagogy, including the tendency of contemporary students to over-estimate their information seeking skills, the likelihood that the they will not prioritize library skills and exercises unless they have a high grading weight, and their general lack of preparedness for scholarly research. This investigation also highlighted the need to better prepare biology graduate students for their role as teaching assistants, and the benefit that they received from having a librarian assist with information literacy instruction. The broad characterization of millennial students frequently adopted in the literature is problematic on many levels, but more interactive and innovative approaches to information literacy instruction are necessary to meet the expectations of this generation. Offering opportunities for first year students to understand the scholarly literature of their discipline and apply it to their own research is essential in the development of future skills, both within and beyond their immediate academic courses. The authors also strongly believe that Bernard Lonergan's Generalized Empirical Method (GEM) is a valuable tool for effecting positive change in today's increasingly complex information landscape for students and instructors alike. GEM is easily incorporated with the ACRL Framework and offers a useful framework for all instruction librarians, even those not affiliated with the sciences.

\section{REFERENCES}

ACRL Framework for Information Literacy for Higher Education. Retrieved April 24, 2017 from http://www.ala.org/acrl/standards/ilframework\#inquiry

Abrizah, A., Inuwa, S., \& Afiqah-Izzati, N. (2016). Systematic literature review informing LIS professionals on embedding librarianship roles. The Journal of Academic Librarianship 42(6), 636-643. https://doi.org/10.1016/j.acalib.2016.08.010

Arp, L., Woodard, B. S., Lindstrom, J., \& Shonrock, D. D. (2006). Faculty-librarian collaboration to achieve integration of information literacy. Reference \& User Services Quarterly, 46(1), 18-23. 
PREPRINT: Enhancing information literacy using Bernard Lonergan's Generalized Empirical Method

Badke, W. B. (2012). Teaching research processes: the faculty role in the development of skilled student researchers. Witney, UK : Chandos Publishing.

Bandyopadhyay, A. (2013). Measuring the disparities between biology undergraduates' perceptions and their actual knowledge of scientific literature with clickers. Journal of Academic Librarianship, 39(2), 194-201. https://doi.org/10.1016/j.acalib.2012.10.006

Beile, P. M. (2003). Effectiveness of course-integrated and repeated library instruction on library skills of education students. Journal of Educational Media \& Library Sciences, 40(3), 271-277.

Bent, M. (2008). Information literacy and the transition from secondary to tertiary education: measuring perceptions. Enhancing Learning in the Social Sciences, 1(1), 1-11.

https://doi.org/10.11120/elss.2008.01010007

Bloom, B. (2007). Information fluency is now a core competency on campus. In Special Libraries Association Contributed Papers. Retrieved November 13, 2016 from http://www.sla.org/contributed_pap/

Bloom, B., \& Deyrup, M. M. (2015). The SHU research logs: Student online search behaviors transscripted. The Journal of Academic Librarianship, 41(5), 593-601.

https://doi.org/10.1016/j.acalib.2015.07.002

Bourke, B., \& Mechler, H. S. (2010). A new Me generation? The increasing self-interest among millennial college students. Journal of College \& Character, 11(2-9).

Bowden, T. S., \& DiBenedetto, A. (2001). Information literacy in a biology laboratory session. An example of librarian-faculty collaboration. Research Strategies, 18, 143-149

Brancato, L., Chan, T., \& Contento, A. (2016). Broad collaboration to improve biological sciences students' writing and research skills. Issues in Science and Technology Librarianship, 84. Retrieved December 16, 2016 from http://www.istl.org/16-spring/tips1.html. 
PREPRINT: Enhancing information literacy using Bernard Lonergan's Generalized Empirical Method

Brasley, S. S. (2008). Effective librarian and discipline faculty collaboration models for integrating information literacy into the fabric of an academic institution. New Directions for Teaching \& Learning, 2008(114), 71-88. https://doi.org/10.1002/t1.318

Brown, C., \& Krumholz, L. R. (2002). Integrating Information Literacy into the Science Curriculum. College \& Research Libraries, 63(2), 111-23.

Buschman, J. (2007). Talkin' 'bout my (neoliberal) generation: Three theses. Progressive Librarian, (29), $28-40$.

Cervetti, G., \& Pearson, P. D. (2012). Reading, writing, and thinking like a scientist. Journal of Adolescent \& Adult Literacy, 55(7), 580-586. https://doi.org/10.1002/JAAL.00069

Connaway, L. S., Dickey, T. J., \& Radford, M. L. (2011). "If it is too inconvenient I'm not going after it:" Convenience as a critical factor in information-seeking behaviors. Library and Information Science Research, 33, 179-190. https://doi.org/10.1016/j.lisr.2010.12.002

Cronin, B. (2001). Foundations of philosophy: Lonergan's cognitional theory and epistemology. Nairobi: Consolata Institute of Philosophy Press.

Dalal, H. A., Kimura, A. K., \& Hofmann, M. A. (2015). Searching in the wild: Observing informationseeking behavior in a discovery tool. In Proceedings of the ACRL (pp. 668-675). Retrieved November 13, 2016 from

http://www.ala.org/acrl/sites/ala.org.acrl/files/content/conferences/confsandpreconfs/2015/Dalal_Kimura_ Hofmann.pdf

Dempsey, M., \& Valenti, A. M. (2016). Student use of keywords and limiters in web-scale discovery searching. The Journal of Academic Librarianship, 42, 200-206.

https://doi.org/10.1016/j.acalib.2016.03.002 
PREPRINT: Enhancing information literacy using Bernard Lonergan's Generalized Empirical Method

Dewey, B. I. (2004). The embedded librarian: strategic campus collaborations. Resource Sharing \& Information Networks, 17(1-2), 5-17.

Douglas, V. A., \& Rabinowitz, C. E. (2016). Examining the relationship between faculty-librarian collaboration and first-year students' information literacy abilities. College and Research Libraries, 77(2), 144-163. https://doi.org/10.5860/crl.77.2.144

Drewes, K., \& Hoffman, N. (2010). Academic embedded librarianship: An introduction. Public Services Quarterly, 6(2), 75-82. https://doi.org/http://dx.doi.org/10.1080/15228959.2010.498773

Dungy, G.J. (2011). Testing our assumptions about generational cohorts. In FA. Bonner, A.F. Marbley, \& M.F. Howard-Hamilton (Eds.) Diverse Millennial Students in College: Implications for Faculty and Student Affairs. (pp.5-21). Sterling, VA: Stylus Pub.

Emlen, J. M. (1966). The role of time and energy in food preference. American Naturalist 100:611-617.

Ferguson, J. E., Neely, T. Y., \& Sullivan, K. (2006). A Baseline Information Literacy Assessment of Biology Students. Reference \& User Services Quarterly, (2). 61-71.

Ferrer-Vinent, I., Bruehl, M., Pan, D., \& Jones, G. L. (2015). Introducing scientific literature to honors general chemistry students: Teaching information literacy and the nature of research to first-year chemistry students. Journal of Chemical Education, 92(4), 617-624. https://doi.org/10.1021/ed500472v

Ferrer-Vinent, I., \& Carello, C. A. (2011). The lasting value of an embedded, first-year, biology library instruction program. Science \& Technology Libraries, 30(3), 254-266.

https://doi.org/10.1080/0194262X.2011.592789

Firooznia, F., \& Andreadis, D. K. (2006). Information literacy in Introductory Biology. Journal of College Science Teaching, 35(6), 23-27.

Freeman, E., \& Lynd-Balta, E. (2010). Developing information literacy skills early in an undergraduate curriculum. College Teaching, 58(3), 109-115. https://doi.org/10.1080/87567550903521272 
PREPRINT: Enhancing information literacy using Bernard Lonergan's Generalized Empirical Method

Freiburger, G., Martin, J. R., \& Nuñez, A. V. (2016). An embedded librarian program: Eight years on. Medical Reference Services Quarterly, 35(4), 388-396. https://doi.org/10.1080/02763869.2016.1220756

Fullerton, D. S. (2013). What students say about their own sense of entitlement. New Directions for Teaching and Learning, (135), 31-36.

Fuselier, L., \& Nelson, B. (2011). A Test of the efficacy of an information literacy lesson in an introductory biology laboratory course with a strong science-writing component. Science \& Technology Libraries, 30(1), 58-75. https://doi.org/10.1080/0194262X.2011.547101

Gilbert, J. K. (2009). Using assessment data to investigate library instruction for first year students. Communications in Information Literacy, 3(2), 181-192.

Grallo, R. (2016). Personal differences in the application of Generalized Empirical Method. Lonergan Review, 7(1), 48-61.

Gregory, K. (2013). Laboratory logistics: Strategies for integrating information literacy instruction into science laboratory classes. Issues in Science and Technology Librarianship, (74). Retrieved December 15, 2016 from http://www.istl.org/13-fall/refereed2.html

Hartman, P., Newhouse, R., \& Perry, V. (2014). Building a sustainable life science information literacy program using the train-the-trainer model. Issues in Science and Technology Librarianship, 77. Retrieved December 15, 2016 from http://www.istl.org/14-summer/refereed1.html

Head, A. J. (2013). Learning the Ropes: How Freshmen Conduct Course Research Once They Enter College (SSRN Scholarly Paper No. ID 2364080). Rochester, NY: Social Science Research Network. Retrieved from https://papers.ssrn.com/abstract=2364080 (free account required to download pdf).

Jacklin. M.L. \& Robinson, K. (2013). Evolution of various library instruction strategies: Using student feedback to create and enhance online active learning. Partnership: The Canadian Journal of Library \& Information Practice \& Research 8(1), 1-21. 
PREPRINT: Enhancing information literacy using Bernard Lonergan's Generalized Empirical Method

Jacob, N., \& Heisel, A. P. (2008). A faculty-librarian partnership for investigative learning in the introductory biology laboratory. Journal of College Science Teaching, 37(4), 54-59.

Jacobs, D. L., Dalal, H. A., \& Dawson, P. H. (2016). Integrating chemical information instruction into the chemistry curriculum on borrowed time: The multiyear development and evolution of a virtual instructional tutorial. Journal of Chemical Education, 93(3), 452-463.

https://doi.org/10.1021/acs.jchemed.5b00427

Kesselman, M. A., \& Watstein, S. B. (2009). Creating opportunities: Embedded librarians. Journal of Library Administration, 49(4), 383-400. https://doi.org/10.1080/01930820902832538

Kim, S. U., \& Shumaker, D. (2015). Student, librarian, and instructor perceptions of information literacy instruction and skills in a first year experience program: A case study. The Journal of Academic Librarianship, 41(4), 449-456. https://doi.org/10.1016/j.acalib.2015.04.005

Kirschner, P. A., \& van Merriënboer, J. J. (2013). Do learners really know best? Urban legends in education. Educational psychologist, 48(3), 169-183.

Knowlton, D. S., \& Hagopian, K. J. (2013). From entitlement to engagement: Affirming millennial students' egos in the higher education classroom. San Francisco: Jossey-Bass.

Kuhlthau CC. (1991). Inside the search process: Information seeking from the user's perspective. Journal of the American Society for Information Science, 42(5), 361-371.

Kuhlthau. C.C. (2004). Seeking meaning : A process approach to library and information services. Westport, Conn.: Libraries Unlimited.

Lantz, C. (2016). Information literacy in the lab: Graduate teaching experiences in first-year biology. Issues in Science and Technology Librarianship 85. Retrieved December 16, 2016 from http://istl.org/16-fall/refereed5.html 
PREPRINT: Enhancing information literacy using Bernard Lonergan's Generalized Empirical Method

Leckie, G. J. (1996). Desperately seeking citations: Uncovering faculty assumptions about the undergraduate research. Journal of Academic Librarianship, 22(3), 201-208.

Leonard, E., \& McCaffrey, E. (2014). Virtually embedded: The librarian in an online environment. Chicago: Association of College \& Research Libraries.

Liddy, R. M. (2014). Transforming faculty development: A recent experiment. Presented at the Revisiting Lonergan's Anthropology, Gregorian University, Rome, Italy.

Loesch, M. (2017). "Research instruction: Is there a disconnect between high school and college expectations." Presented at the 18th annual VALE / NJ ACRL / NJLA CUS Users' Conference, Rutgers University, Piscataway, NJ. January 6, 2017.

Lonergan, B. J. F. (1957). Insight: A study of human understanding. New York: Harper. Republished 1992 as Collected Works of Bernard Lonergan, Volume 3; Toronto: University of Toronto Press.

Lonergan, B. J. F. (1971). Method in theology. Toronto: University of Toronto Press, republished 1990 for the Lonergan Research Institute of Regis College.

Lonergan, B. J. F., Doran, R. M., \& Crowe, F. E. (1993). Topics in education: The Cincinnati lectures of 1959 on the philosophy of education. Toronto: University of Toronto Press. Republished 2005 as Collected works of Bernard Lonergan. The Cincinnati lectures of 1959 on the philosophy of education Volume 10. Toronto: University of Toronto Press.

MacArthur, R. H. and Pianka, E. R. (1966). On optimal use of a patchy environment. American Naturalist 100:603-609.

Marroum, R.-M. (2004). The role of insight in science education: An introduction to the cognitional theory of Bernard Lonergan. Science \& Education, 13(6), 519-540.

Manuel, K. (2002). Teaching information literacy to generation Y. Journal of Library Administration 36(1-2), 195-217. 
PREPRINT: Enhancing information literacy using Bernard Lonergan's Generalized Empirical Method

Pirolli, P. (2007). Information foraging theory: adaptive interaction with information. Oxford ; New York : Oxford University Press, 2007.

Praxis Program of the Advanced Seminar on Mission. Retrieved November 13, 2016, from INSTITUION WEBSITE

Reale, M. (2015). Becoming an embedded librarian: making connections in the classroom. Chicago: ALA Editions.

Reed, K. \& Thompson, D. (2016). Dynamic duos: Blended instruction and faculty-librarian collaboration. In R. McClure (Ed.), Rewired: Research-writing partnerships within the frameworks (pp. 209-223). Chicago: Association of College and Research Libraries.

Robinson, R. L., \& McDonald, J. E. (2014). Developing skills in second year biological science undergraduates. Bioscience Education, 22(1), 42-53.

Roscoe, K. (2004). Lonergan's Theory of cognition, constructivism and science education. Science \& Education, 13(6), 541-551.

Rose-Wiles, L.M, \& Hofmann, M. A. (2013). Still desperately seeking citations: Undergraduate research in the age of web-scale discovery. Journal of Library Administration, 53(2), 147-166. https://doi.org/10.1080/01930826.2013.853493

Sandstrom, P. E. (1994). An optimal foraging approach to information seeking and use. The Library Quarterly: Information, Community, Policy, (4), 414-449.

Schoener, T. W. (1971). Theory of feeding strategies. Annual Review of Ecology and Systematics 2:369404

SHU Fact Book (2015-16). Retrieved December 31, 2016 from http://www.shu.edu/institutionalresearch/upload/2015-16-Fact-Book.pdf. 
PREPRINT: Enhancing information literacy using Bernard Lonergan's Generalized Empirical Method

Smith, J. K., DeLong, K., Given, L. M., Julien, H., \& Ouellette, D. (2013). Information literacy proficiency: Assessing the gap in high school students' readiness for undergraduate academic work. Library and Information Science Research, 35(2), 88-96. https://doi.org/10.1016/j.lisr.2012.12.001

Thaler, V. S. (2013). Teaching historical research skills to generation Y: one instructor's approach. The History Teacher, (2), 267-281.

Thompson, L. \& Blankinship, L.A. (2015). Teaching Information Literacy Skills to Sophomore-Level Biology Majors. Journal of Microbiology \& Biology Education, 16(2), 29-33

Varlejs, J., Stec, E. \& Kwon, H. (2014). Factors affecting students' information literacy as they transition from high school to college. School Library Research, 17. Retrieved November 13, 2016 from http://www.ala.org/aasl/slr/volume17/varlejs-stec-kwon

Warwick, C., Rimmer, J., Blandford, A., Gow, J., \& Buchanan, G. (2009). Cognitive economy and satisficing in information seeking: A longitudinal study of undergraduate information behavior. Journal of the American Society for Information Science \& Technology, 60(12), 2402-2415.

Weiler, A. (2005). Information-seeking behavior in Generation Y students: Motivation, critical thinking, and learning theory. The Journal of Academic Librarianship, 31, 46-53.

https://doi.org/10.1016/j.acalib.2004.09.009

Winterman, B. (2009). Building better biology undergraduates through information literacy integration. Issues in Science and Technology Librarianship, (58). Retrieved November 13, 2016 from http://www.istl.org/09-summer/refereed1.html

Zhang, L. (2016). Is inquiry-based science teaching worth the effort? Science \& Education, 25, 897-915. https://doi:10.1007/s11191-016-9856-0

\section{Acknowledgements}


The research and preparation of this paper reflects the authors' affiliation as GEM Fellows of the Praxis Program of the Advanced Seminar on Mission, the Center for Vocation and Servant Leadership and the Center for Catholic Studies, Bernard J. Lonergan Institute at Seton Hall University, and we gratefully acknowledge this support. We thank Anglin Thevarajah, who initiated and led the drop-in lab assistance sessions in fall 2015 and facilitated discussions with groups of Biology 1201 students. We are grateful to Veronica Amour, instructional designer, for her assistance in embedding the Top Hat exercises into the fall 2016 library presentation. We thank three anonymous reviewers for their constructive comments which greatly improved the original manuscript. The project was supported by a University Research Release, sponsored by the Office of the Provost, to the corresponding author in 2015. 